\title{
Peran Forum Rohis Maros (Foros Maros) Terhadap Pengembangan Dakwah
}

\author{
Nurul Fuadi \\ Ukhwani Ramadani \\ e-mail:nurul.fuadi@umi.ac.id \\ Dosen Tetap Fakultas Agama Islam Universitas Muslim Indonesia
}

\begin{abstract}
Abstrak
Penelitian menggambarkan tentang bagaimana pelaksanaan kegiatan Forum Rohis Maros (Foros Maros) terhadap Pengembangan Dakwah di Kabupaten Maros serta apa saja faktor pendukung dan faktor penghambat dari pelaksanaan kegiatan tersebut. Hal ini juga berguna untuk memberikan pemahaman kepada pengurus Forum Rohis Maros (Foros Maros) serta setiap orang yang terlibat dalam kegiatannya agar dapat lebih memaksimalkan setiap kegiatan yang dijalankan agar proses pengembangan dakwah di Kabupaten Maros dapat berjalan dengan baik. Penelitian ini menerapkan pendekatan kualitatif dengan teknik pengumpulan data melalui observasi, wawancara, dan dokumentasi serta menggunakan Teknik purposive sampling dalam pengambilan sampel. Sementara itu, jika dilihat dari sifat datanya yang dikumpulkan bersifat deskriptif atau kata-kata tertulis dari orang-orang dengan perilaku yang dapat diamati. Dengan menganalisis data yang diperoleh meliputi kegiatan pengumpulan data, penyajian data, reduksi data, dan kesimpulan-kesimpulan/memverifikasi hal-hal yang penting dan dipelajari serta menganalisis hingga menjawab permasalahan yang ada.

Hasil penelitian yang dilakukan oleh peniliti menunjukkan bahwa keberadaan Forum Rohis Maros sangat dianggap penting sebagai Lembaga dakwah yang ruang lingkupnya meliputi para pelajar demi mengembangkan dakwah di Kabupaten Maros dengan berbagai pelaksanaan kegiatan yang telah dilakukan secara maksimal. Hal ini dipengaruhi oleh faktor pendukung antara lain, Foros Maros selalu berusaha melaksanakan manajemen dakwah sesuai dengan tahapannya yakni perencanaan dakwah dengan menyusun timeline pelaksanaan program kerja, pengorganisasian dakwah dengan membagi job description sesuai dengan minat para anggota rohis, penggerakkan dakwah yang berusaha terus dilakukan oleh ketua Foros Maros serta rohis sekolah, serta pengendalian dan evaluasi dakwah yang dilakukan setelah pelaksanaan kegiatan berlangsung. Adapun faktor penghambat dalam setiap pelaksanaan kegiatan Foros Maros ialah permasalahan anggaran, kurangnya komunikasi dan koordinasi antar anggota, serta kurangnya dukungan dari pihak sekolah dan pemerintah.
\end{abstract}

Keyword: Foros Maros, Lembaga Dakwah, Rohis

\section{Latar Belakang Masalah}

Islam merupakan agama yang universal, mencakup seluruh aspek kehidupan manusia, mulai dari persoalan sosial, budaya, politik, bahkan ekonomi diatur dalam konsepsi pengetahuan yang berdasarkan pada Al-Qur'an dan Hadis. Pemahaman mengenai Islam tidak hanya dibatasi oleh mereka yang mempercayainya sebagai agama, namun mencakup seluruh makhluk yang diciptakan oleh Allah, sebab Islam adalah agama yang Rahmatan lil al'alaamiin (rahmat bagi seluruh alam).

Dalam Islam, dakwah merupakan sebuah upaya dalam proses penyampaian ajaran Islam. Sayyid Quthub memandang dakwah sebagai usaha untuk mewujudkan sistem Islam dalam kehidupan nyata dari tataran yang paling kecil, seperti keluarga, hingga yang paling besar, seperti negara atau ummah dengan tujuan mencapai kebahagiaan dunia dan akhirat. (Ilyas Ismail,2011:29) 
Dakwah dalam praktiknya merupakan kegiatan yang sudah cukup tua, yaitu sejak adanya tugas dan fungsi yang harus diemban oleh manusia dibelantara kehidupan dunia ini. Oleh sebab itu, eksistensi dakwah sebagai proses penyelematan umat manusia dari berbagai persoalan yang merugikan kehidupannya, merupakan bagian dari tugas dan fungsi manusia yang sudah direncanakan sejak awal penciptaan manusia sebagai khalifah fi al-ardh. ( Ejang AS, 2009:1)

Dakwah merupakan suatu proses yang aktif, persuasif, dan komperehensif. Dengan kata lain, pendakwah harus mencari orang sebagai mitra dakwah, lalu memberikan persuasi dan mengajaknya ke jalan Allah SWT. Kesempurnaan dakwah adalah membentuk mitra dakwah menjadi pendakwah. Setiap orang tidak dapat terlepas dari kegiatan dakwah, baik sebagai pendakwah maupun mitra dakwah. Apapun yang berkaitan dengan Islam, sudah dipastikan ada unsur dakwahnya. Islam dapat bergerak dan hidup karena dakwah. (Moh. Ali Aziz,2005:5)

Terdapat konsep dakwah yang mengedepankan cara-cara simpatik, bijaksana, dan lebih humanis, seperti pendekatan sosial dan budaya yang diterima oleh masyarakat luas. Memperhatikan ruang dan waktu, topik-topiknya aktual, menyentuh kebutuhan dasar mad'u dan isu-isu terkini dalam masyarakat. Namun, terdapat pula kelompok Islam tertentu yang berdakwah dengan cara yang agresif, bahkan ekstrem. Dakwah dengan cara yang esktrem ini tentu tidak akan memecahkan masalah atau persoalan-persoalan ummat, sebaliknya menambah persoalan dalam masyarakat, bukan simpati yang diperolah, tetapi antipati, baik dari golongan nonmuslim maupun dari umat Islam sendiri. (Aripuddin,2011:25)

Terdapat berbagai metode dakwah yang dijelaskan dalam Al-Qur'an, salah satunya merujuk pada surah An-Nahl: 125.

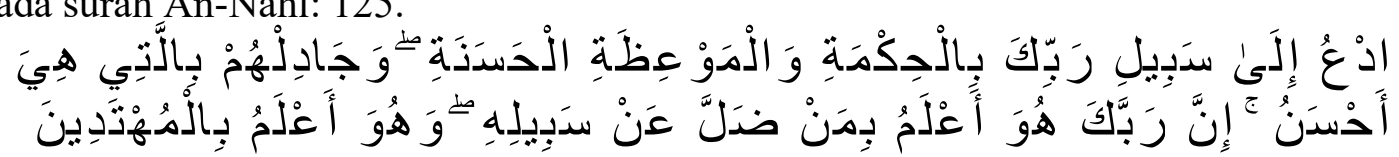

Terjemahnya:

"Serulah manusia kepada jalan Tuhanmu dengan hikmah dan pelajaran yang baik. Sesungguhnya Tuhanmu Dialah yang lebih mengetahui tentang siapa yang tersesat dijalanNya. Dan dialah yang lebih mengetahui orang-orang yang mendapat petunjuk."

M. Quraish Shihab dalam penafsirannya, terkait dengan surah An-Nahl ayat 125 mengungkapkan wahai nabi Muhammad, serulah yakni lanjutkanlah usahamu untuk menyeru semua yang engkau sanggup seru kepada jalan yang ditunjukkan Tuhanmu yakni ajaran Islam dengan hikmah dan pengajaran yang baik dan bantahlah mereka yakni siapa pun yang menolak atau meragukan ajaran Islam dengan cara yang terbaik. Itulah tiga cara mendidik yang hendaknya engkau tempuh menghadapi manusia yang beraneka ragam peringkat dan kecenderungannya; jangan hiraukan cemoohan, atau tuduhan-tuduhan berdasar kaum musyrikin dan serahkan urusanmu dan urusan mereka kepada Allah, karena sesungguhnya Tuhanmu yang selalu membimbing dan berbuat baik kepadamu. Dialah sendiri yang lebih mengetahui diri siapa pun yang menduga tahu tentang siapa yang bejat jiwanya sehingga tersesat dari jalan-jalan-Nya dan Dialah saja juga lebih mengetahui orang-orang yang sehat jiwanya sehingga mendapat petunjuk. (M. Quraish Shihab,2002:385-386)

Masa remaja merupakan suatu rangkaian perubahan-perubahan yang dialami oleh remaja. Tidak saja perubahan di dalam dirinya, tetapi perubahan-perubahan di luar dirinya seperti halnya perubahan sikap orang tua, anggota keluarga lain dan sebagainya, ditambah pula dengan jadinya perubahan pergaulan dari orang tua dan keluarga menjadi pergaulan dengan 
teman sebaya yang berarti berkenalan dengan norma, nilai, tata cara dan adat istiadat yang baru pula. (Panut Panuju,2005:91)

Beberapa tahun terakhir, terdapat beberapa kasus yang telah terjadi. Tidak sedikit remaja yang terlibat dalam tindakan kriminal, bahkan asusila. Dilansir dari Tempo.co, bahwa Komisi Perlindungan Anak Indonesia (KPAI) mencatat kasus tawuran di Indonesia meningkat $1,1 \%$ sepanjang 2018 dan kasus tersebut tidak sedikit melibatkan siswa.(Julnis Firmansyah,Tempo.co) Berbagai tindakan yang dilakukan oleh para remaja tentu tidak terlepas dari pengaruh lingkungannya, mulai dari keluarga, buku yang dibaca, film yang ditonton, hingga teman sepermainannya memberikan dampak yang besar dalam perubahan pola pikir serta perilaku dalam keseharian.

Kasus tersebut diatas harusnya menegaskan bahwa dakwah dan remaja harusnya menjadi satu kesatuan yang tak terpisahkan. Pada masa remaja seperti inilah, sangat penting untuk membangun kerangka berpikir berdasarkan dengan nilai-nilai Islam, pada masa ini pula para remaja mulai mencari jati dirinya. Sejak remaja, nilai-nilai Islam sejatinya menjadi bagian positif yang harus ditanamkan.

Dimulai dengan membuka ruang bagi para remaja untuk beraktivitas dalam kelompok keagamaan, mengkaji ajaran-ajaran Islam bersama dengan teman-temannya hingga menjadikan Al-Qur'an sebagai pedoman hidup dalam menjalankan keseharian. Berinteraksi lebih banyak dengan dunia Islam secara tidak langsung akan membangun kebudayaan yang berdasarkan dengan nilai-nilai Islam, salah satunya adalah dengan menginisiasi hadirnya lembaga/organisasi dakwah untuk menghimpun para remaja.

Atas dasar itulah, beberapa alumni rohis Sekolah Menengah Atas (SMA) di Kabupaten Maros menginisiasi sebuah ruang belajar dengan konsep yang terus diupayakan relevan dengan remaja saat ini. Tujuannya adalah untuk membantu pengembangan pemahaman remaja atau siswa SMA mengenai ajaran agama Islam dengan menghimpun setiap rohis sekolah di Kabupaten Maros. Terbentuklah Forum Rohis Maros (Foros Maros) secara resmi sejak hari Sabtu, 03 Oktober 2015 di Rumah Makan Idaman Kabupaten Maros.

Sejak berdirinya, Foros Maros telah melakukan berbagai kegiatan atau program kerja sebagai upaya dalam pengembangan dakwah serta menghimpun setiap rohis sekolah yang ada di Kabupaten Maros. Meski demikian, pemahaman serta pengamalan terhadap agama di kalangan remaja belum sepenuhnya maksimal. Akan tetapi, Foros Maros sebagai ruang belajar dan controlling system terus berusaha untuk dapat memberikan dampak yang positif karena adanya berbagai strategi dakwah yang dikemas secara menarik.

Berangkat dari permasalahan tersebut, maka penulis berkeinginan untuk mengadakan penelitian yang berjudul "Peran Forum Rohis Maros (Foros Maros) terhadap Pengembangan Dakwah di Kabupaten Maros".

\section{Rumusan Masalah}

\section{Rumusan Masalah dan Batasan Masalah}

Berdasarkan latar belakang di atas, dapat dikemukakan rumusan masalah dari penelitian ini adalah bagaimana peran Forum Rohis Maros (Foros Maros) terhadap pengembangan dakwah di Kabupaten Maros?

\section{Batasan Masalah}

Untuk menghindari kesalahpahaman dan penyimpangan arah dalam pembahasan penelitian ini maka perlu adanya batasan masalah. Adapun yang menjadi batasan masalah dalam penelitian ini antara lain:

a. Bagaimana pelaksanaan kegiatan Forum Rohis Maros (Foros Maros) terhadap pengembangan dakwah di Kabupaten Maros? 
b. Apa saja faktor pendukung dan penghambat dalam pelaksanaan kegiatan Forum Rohis Maros (Foros Maros) terhadap pengembangan dakwah di Kabupaten Maros?

\section{A. Tinjauan Rohis di Sekolah dan Madrasah}

\section{Tinjauan Pustakan}

\section{Pengertian Rohis}

Kerohanian Islam (disingkat Rohis) berasal dari dua kata, yaitu kerohanian dan Islam. Kerohanian dalam Kamus Besar Bahasa Indonesia (KBBI), Pusat Bahasa Kementerian Pendidikan Nasional, sebagaimana dikutip oleh Ummu Hanifah, berasal dari kata dasar rohani yang artinya berkaitan dengan roh/rohaniah. Diberi imbuhan ke-an menjadi kerohanian yang berarti sifat-sifat rohani atau perihal rohani. (Nasrullah Nurdin,2018:20)

Sedangkan Islam secara etimologis berasal dari Bahasa arab, salima yang berarti selamat sentosa. Dari kata ini dibentuk aslama yang berarti memelihara dalam keadaan yang selamat sentosa, dan juga berarti menyerahkan diri, tunduk, pauh, dan taat. (Nasrullah Nurdin,2018:20)

Berdasarkan hal tersebut, rohis adalah ruang yang terbuka bagi setiap siswa dan siswi untuk belajar tentang ajaran agama Islam berdasarkan Al-Qur'an dan Hadis.

\section{Tujuan dan Ruang Lingkup Rohis}

Kerohanian Islam merupakan kegiatan ekstrakurikuler keagamaan Islam yang hadir di sekolah-sekolah dengan adanya Surat Keputusan Mendikbud Nomor 0209/4/1984 tentang Perbaikan Kurikulum Sekolah Menengah Umum Tingkat Atas. Surat keputusan tersebut menghendaki agar sekolah-sekolah mengadakan program pembinaan bagi peserta didiknya melalui program ekstrakurikuler yang difungsikan sebagai wadah pembinaan, pelatihan, dan pengembangan potensi diri peserta didik. (Nasrullah Nurdin,2018:27-28)

Kegiatan ekstrakurikuler dapat diartikan sebagai program pembinaan di luar jam pelajaran. Kegiatan ini mencakup pemantapan dan pembentukan kepribadian yang utuh termasuk pengembangan minat dan bakat peserta didik, kegiatan-kegiatan yang dilakukan tentu membutuhkan sistematika atau manajemen yang baik agar dapat berjalan sesuai dengan yang diharapkan.

Selain itu, disebutkan dalam Panduan Kegiatan Ekstrakurikuler Pendidikan Agama Islam (PAI) Kementerian Agama, bahwa peran dan tujuan rohis antara lain sebagai berikut:

a) Meningkatkan pemahaman terhadap agama sehingga mampu mengembangkan dirinya sesuai norma agama serta mampu mengamalkannya.

b) Meningkatkan kemampuan peserta didik sebagai anggota masyarakat.

c) Menyalurkan dan mengembangkan potensi dan bakat peserta didik.

d) Melatih sikap disiplin, kejujuran, kepercayaan, dan tanggung jawab dalam menjalankan tugas.

e) Menumbuh-kembangkan akhlak Islami yang mengintegrasikan hubungan dengan Allah, Rasul, manusia, dan alam sekitar.

f) Mengembangkan sensitivitas peserta didik dalam melihat persoalan-persoalan sosialkeagamaan sehingga menjadi insan yang proaktif terhadap permasalahan sosial dan dakwah Islamiah

g) Memberikan bimbingan dan arahan serta pelatihan kepada peserta didik.

h) Memberi peluang peserta didik agar memiliki kemampuan untuk komunikasi yang baik.

i) Melatih kemampuan peserta didik untuk bekerja dengan sebaik-baiknya secara mandiri maupun kelompok. 
Menumbuh-kembangkan kemampuan peserta didik untuk memecahkan masalah sehari-hari. (Nasrullah Nurdin,2018:29-30)

Tujuan pembetukan rohis juga diperkuat dengan adanya Undang-Undang Republik Indonesia No. 20 Tahun 2003 tentang Sistem Pendidikan Nasional pada Bab II Pasal 3 yang menyatakan bahwa:

Pendidikan Nasional berfungsi mengembangkan kemampuan dan membentuk watak serta peradaban bangsa yang bermartabat dalam rangka mencerdaskan kehidupan bangsa, bertujuan untuk berkembangnya potensi peserta didik agar menjadi manusia yang beriman dan bertakwa kepada Tuhan Yang Maha Esa, berakhlak mulia, sehat, berilmu, cakap, kreatif, mandiri, dan menjadi warga negara yang demokratis serta tanggung jawab. (Undang-Undang No. 20 Tahun 2003 Tentang Sistem Pendidikan Nasional)

Keberadaan rohis juga secara tidak langsung bertujuan untuk membantu Kementerian Pendidikan dan Kebudayaan RI agar dapat memenuhi Dimensi Pendidikan Karakter yang terdiri atas:

a) Olah Hati (Etik), Individu yang memiliki kerohanian mendalam, beriman, dan bertakwa.

b) Olah Pikir (Literasi), Individu yang memiliki keunggulan akademis sebagai hasil pembelajaran dan pembelajar sepanjang hayat.

c) Olah Rasa (Estetik), Individu yang memiliki integritas moral, rasa berkesenian, dan berkebudayaan.

d) Olahraga (Kinestetik), Individu yang sehat dan mampu berpartisipasi aktif sebagai warga negara.

Di dalam Al-Qur'an sendiri diterangkan bahwa sosok pemuda layak diberikan kepemimpinan dan pelopor perubahan karena potensi alamiahnya. Sebagaimana firman Allah swt di dalam Al-Qur'an surah Al-Kahf ayat 13:

Terjemahnya:

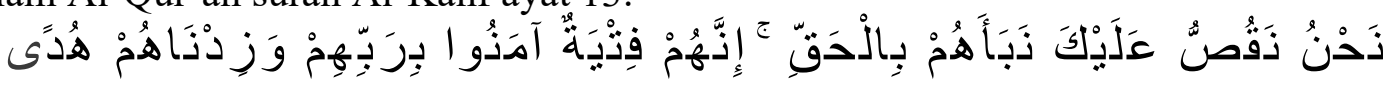

"Kami kisahkan kepadamu (Muhammad) cerita ini dengan benar. Sesungguhnya mereka adalah pemuda-pemuda yang beriman kepada Tuhan mereka, dan Kami tambah pula untuk mereka petunjuk"

Berdasarkan ayat tersebut, dapat disimpulkan bahwa pemuda memegang peran penting dan dianggap memiliki potensi yang lebih besar dalam membangun peradaban, sebab pemuda adalah tongkat estafet bagi tegaknya ajaran-ajaran Islam di seluruh dunia.

\section{Manajemen Rohis}

Beban dakwah ditanggung secara Bersama-sama sehingga ringan. Berat sama dipikul dan ringan sama dijinjing. Dengan demikian, diharapkan pencapaian sasaran-sasaran dakwah dapat terlaksana dengan baik. Sebagaimana firman Allah SWT didalam Q.S. Ash-Shaff [61]: ayat 4:

Terjemahnya:

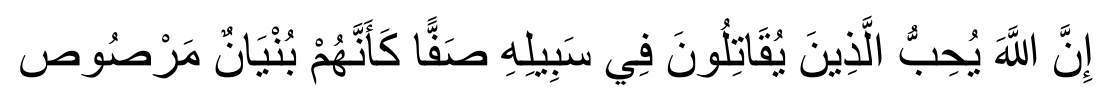

"Sesungguhnya Allah menyukai orang yang berperang dijalan-Nya dalam barisan yang teratur seakan-akan mereka seperti suatu bangunan yang tersusun kokoh."

Hal ini merupakan pemberitaan dari Allah Swt. yang menyatakan kecintaan-Nya kepada hamba-hamba-Nya yang beriman. Apabila mereka berbaris dengan teratur menghadapi musuh-musuh Allah dalam medan pertempuran, mereka berperang di jalan Allah melawan 
orang-orang yang kafir terhadap Allah agar kalimah Allah-lah yang tertinggi dan agamaNyalah yang menang lagi berada di atas agama-agama lainnya.

Surat Keputusan (SK) Dirjen Pendidikan Islam (Pendis) tentang Penyelenggaraan Kegiatan Ekstrakulikuler Pendidikan Agama Islam (PAI) pada sekolah, dinyatakan bahwa rohis merupakan salah satu jenis kegiatan ekstrakulikuler PAI di sekolah dalam kegiatannya terdapat: pesantren kilat, pembiasaan akhlak mulia, tuntas baca tulis Al-Qur'an ibadah ramadhan, wisata rohani, peringatan hari besar Islam, dan pekan keterampilan dan seni PAI. tahapan:

Pengembangan kegiatan ekstrakulikuler pilihan di sekolah dapat dilakukan melalui
a) Analisis sumber daya yang diperlukan dalam penyelenggaraan kegiatan.
b) Identifikasi kebutuhan, potensi, dan minat peserta didik.
c) Menetapkan bentuk kegiatan ekstrakulikuler.
d) Mengupayakan sumber daya (pelatih/instruktur).
e) Menyusun program kegiatan.

\section{B. Pengembangan Dakwah}

1) Pengertian Lembaga Dakwah

Lembaga dakwah terdiri atas dua suku kata, yakni lembaga dan dakwah. Secara bahasa, Lembaga berarti badan atau organisasi yang bermaksud melakukan sesuatu penyelidikan keilmuan atau melakukan suatu usaha. (KBBI,2016:389). Sedangkan dakwah berarti penyiaran agama dan pengembangannya di kalangan masyarakat, seruan untuk memeluk, mempelajari, dan mengamalkan ajaran agama. (KBBI,2016:487).

2) Tujuan dan Fungsi Lembaga Dakwah

Keberadaan organisasi atau Lembaga dakwah Islam menjadi sangat penting dalam melestarikan dan menebarkan nilai-nilai Islam kepada masyarakat melalui implementasi berbagai program, kebijakan maupun pemikirannya.

Dengan demikian organisasi dakwah seharusnya punya peran yang sangat strategis dalam mempengaruhi kehidupan sosial masyarakat yang membawa pada kedamaian, kebaikan bersama, dan fungsinya menjalankan perintah dakwah ilahiyah.(Saputra Rizky,2016:20-21)

3) Manajemen Lembaga Dakwah

Menurut Mahmuddin, manajemen dakwah adalah suatu proses dalam memanfaatkan sumber daya (insani dan alam) dan dilakukan untuk merealisasikan nilai-nilai ajaran Islam sebagai tujuan Bersama. Sedangkan menurut M. Munir mendefinisikan manajemen dakwah sebagai pengaturan secara sistematis dan koordinatif dalam kegiatan atau aktivitas dakwah yang dimulai sebelum pelaksanaan sampai akhir dari kegiatan dakwah.

Manajemen dakwah menjadi hal yang sangat dibutuhkan dalam proses atau upaya pengembangan dakwah. Seperti layaknya ilmu manajemen secara umum, pelaksanaan manajemen dakwah juga akan melalui tahapan langkah, antara lain: perencanaan, pengorganisasian, penggerakan, pengendalian dan evaluasi dakwah.

\section{Jenis Penelitian}

\section{Metode Penelitian}

Jenis penelitian ini merupakan penelitian studi kasus yang bertujuan untuk memperoleh gambaran secara lengkap dan detail mengenai fenomena tertentu pada suatau objek dan subjek yang memiliki kekhasan. Dengan demikian, pelaksanaan penelitian dengan menggunakan studi kasus adalah menggali informasi sebanyak-banyaknya dan sedalam-dalamnya kemudian mendeskripsikannya dalam bentuk naratif sehingga memberikan gambaran secara utuh tentang fenomena yang terjadi. (Wina Sanjaya,2013:268) 


\section{Metode Pendekatan}

Pendekatan yang digunakan dalam penelitian ini adalah pendekatan kualitatif deskriptif. Maksudnya dalam penelitian kualitatif, data yang dikumpulkan bukan berupa angka-angka, melainkan data berupa wawancara, catatan lapangan, dan dokumentasi pribadi. Adapun data yang dimaksud peneliti adalah data tentang peran Forum Rohis Maros (Foros Maros) terhadap pengembangan dakwah di Kabupaten Maros, yang berupa pelaksanaan kegiatan Foros Maros serta faktor pendukung dan faktor penghambat dalam pelaksanaan kegiatan tersebut.

\section{Metode Pengumpulan Data \\ a. Subjek Penelitian}

Berdasarkan jenisnya, penelitian ini jika dikaitkan dengan pengumpulan data adalah penelitian lapangan (field research). Dalam penentuan sampel penulis menggunakan teknik pengambilan sampel berupa teknik purposive sampling, yaitu teknik yang dilandasi dengan tujuan atau pertimbangan tertentu terlebih dahulu. Oleh karena itu, pengambilan informasi (informan) didasarkan pada maksud yang telah ditetapkan sebelumnya. Purpose dapat diartikan sebagai maksud, tujuan, atau kegunaan. (Muri Yusuf,2014:369) Jadi pengumpulan data ini diperoleh dari orang-orang yang dianggap paling mengetahui tentang kondisi yang diteliti.

Subjeknya adalah orang-orang yang berpartisipasi di dalam kegiatan Forum Rohis Maros (Foros Maros) beserta ruang lingkupnya. Adapun yang menjadi subjek penelitian ini adalah:

1) Dewan Syuro Forum Rohis Maros (Foros Maros) sebanyak satu orang

2) Ketua Umum Forum Rohis Maros (Foros Maros)

3) Ketua Rohis Sekolah yang tergabung sebagai mitra Forum Rohis Maros (Foros Maros) sebanyak 3 orang

4) Pengurus Forum Rohis Maros (Foros Maros) yang terdiri atas sekretaris, bendahara, serta masing-masing koordinator maupun anggota setiap seksi bidang sebanyak 8 orang.

\section{b. Metode Pengumpulan Data}

\section{1) Observasi}

Observasi adalah teknik pengumpulan data dengan cara mengamati secara langsung maupun tidak tentang hal-hal yang terkait dengan penelitian dan mencatatnya pada alat observasi. Hal-hal yang diamati itu biasa gejala-gejala tingkah laku, benda-benda hidup, ataupun benda mati.(Wina Sanjaya,2013:270) Dalam hal ini peneliti melakukan pengamatan terhadap pelaksanaan kegiatan atau program kerja yang dijalankan oleh Forum Rohis Maros (Foros Maros) sebagai upaya yang dilakukan untuk pengembangan dakwah di Kabupaten Maros.

2) Wawancara

Wawancara adalah suatu metode pengumpulan data yang berupa pertemuan dua orang atau lebih secara langsung untuk bertukar informasi dan ide dengan tanya jawab secara lisan sehingga dapat dibangun makna dalam suatu topik tertentu. (Wina Sanjaya,2013:270)

Metode ini digunakan untuk mendapatkan keterangan mengenai peran Forum Rohis Maros (Foros Maros) terhadap pengembangan dakwah di Kabupaten Maros, dengan meninjau dan mempertanyakan bagaimana proses pelaksanaan setiap kegiatan yang dilakukan oleh Forum Rohis Maros (Foros Maros) serta apa saja faktor pendukung dan penghambat bagi jalannya pelaksanaan kegiatan tersebut, serta hal lain yang dianggap berkaitan dengan penelitian yang diangkat. Sesuai dengan subjek penelitian maka peneliti akan mewawancarai beberapa pihak yang tergabung dalam pelaksanaan kegiatan Forum Rohis Maros (Foros Maros).

a) Dewan Syuro Forum Rohis Maros (Foros Maros) sebanyak 1 orang 
b) Ketua Umum Forum Rohis Maros (Foros Maros)

c) Ketua Rohis Sekolah yang tergabung sebagai mitra Forum Rohis Maros (Foros Maros) sebanyak 3 orang

d) Pengurus Forum Rohis Maros (Foros Maros) yang terdiri atas sekretaris, bendahara, serta masing-masing koordinator maupun anggota setiap seksi bidang sebanyak 8 orang

3) Dokumentasi

Dalam penelitian ini yang dimaksud dokumentasi adalah suatu metode pengumpulan data dengan jalan melihat catatan yang sudah ada. Metode dokumentasi diperlukan sebagai metode pendukung untuk mengumpulkan data, karena dalam metode ini dapat diperoleh datadata histories.

Dengan metode dokumentasi ini dapat diperoleh data berupa sejarah terbentuknya Foros Maros, susunan kepengurusan, draf program kerja, draf AD/ART, dokumentasi pelaksanaan kegiatan Foros Maros, serta data-data relevan lainnya.

\section{Metode Pengolahan dan Analisa Data}

Dalam penelitian ini penulis menggunakan teknik analisis deskriptif kualitatif. Proses analisa data ini dimulai dengan menyusun semua data yang telah terkumpul berdasarkan urutan pembahasan yang telah direncanakan.

Agar data yang telah terkumpul tersebut dapat menjawab permasalahan yang diajukan peneliti, maka diperlukan adanya penganalisaan dan penafsiran terhadap data tersebut, dalam usaha memahami kenyataan yang ada untuk menarik kesimpulan. Dengan demikian, secara sistematis langkah-langkah analisa tersebut sebagai berikut:

1) Reduksi Data

Proses reduksi data yang dilakukan oleh peneliti dimulai dengan membuat transkrip wawancara. Dalam penelitian ini, data yang direduksi adalah hasil pengamatan, wawancara, dan dokumentasi yang berkaitan dengan peran Foros Maros terhadap pengembangan dakwah di Kabupaten Maros.

2) Display Data (Penyajian Data)

Setelah melakukan reduksi data, langkah selanjutnya ialah menyajikan data. Penyajian data dalam konteks ini adalah kumpulan informasi yang telah tersusun yang membolehkan penarikan kesimpulan dan pengambilan tindakan. Bentuk display data dalam penelitian kualitatif yang paling sering yaitu teks naratif dan kejadian atau peristiwa di masa lampau. Dengan menyajikan data maka akan memudahkan peneliti untuk memahami data tersebut.

3) Verifikasi Data

Kegiatan utama yang ketiga dalam analisis data yaitu penarikan kesimpulan/verifikasi. Sejak awal pengumpulan data, peneliti telah mencatat dan memberi makna sesuatu yang dilihat atau diwawancarinya.

\section{Profil Forum Rohis Maros (Foros Maros)}

\section{Hasil Penelitian}

Forum Rohis Maros (Foros Maros) adalah lembaga keagamaan pelajar Kabupaten Maros yang dibentuk secara resmi dan independen pada hari Sabtu, tanggal 3 Oktober 2015 di Rumah Makan Idaman Kabupaten Maros. Saat ini Foros Maros bertempat di BTN GMI Tamarampu, Jl. Jenderal Sudirman No. 14 Kecamatan Turikale, Kabupaten Maros. Dalam Mukaddimah Anggaran Dasar (AD) Forum Rohis Maros ini, telah dipaparkan bahwa Foros Maros lahir dari semangat dalam memperjuangkan dakwah Islamiyah.

Muh Alwi Alamsyah selaku ketua umum Foros Maros mengungkapkan bahwa Foros adalah singkatan dari Forum Rohis Maros, yang merupakan suatu wadah atau induk dari rohis- 
rohis sekolah yang ada di kabupaten Maros. Foros Dilandasi karena butuh wadah untuk menjaga kebersamaan dalam dakwah. Selain itu, Foros juga adalah Lembaga Dakwah yang menghimpun rohis di Maros.

Berdasarkan uraian di atas maka dapat disimpulkan bahwa Forum Rohis Maros (Foros Maros) adalah kegaitan tambahan di luar struktur program yang dilaksanakan diluar jam pelajaran dengan tujuan untuk memperkaya, memperluas wawasan pengetahuan dan kemampuan siswa, serta mendorong pengembangan dakwah di Kabupaten Maros.

\section{a. Sejarah Forum Rohis Maros (Foros Maros)}

Sejarah pembentukan Foros Maros ini diawali dengan adanya keinginan bersama untuk membuat sebuah kegiatan dakwah, beberapa dewan pendiri Foros saat itu mengungkapkan bahwa dakwah perlu dibangun secara bersama-sama dengan cara yang terorganisir. Sebagaimana firman Allah SWT didalam Q.S. Ash-Shaff [61]: ayat 4:

Terjemahnya:

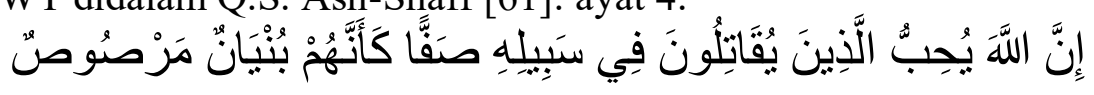

"Sesungguhnya Allah menyukai orang yang berperang dijalan-Nya dalam barisan yang teratur seakan-akan mereka seperti suatu bangunan yang tersusun kokoh."

Proses terbentuknya Lembaga Dakwah ini diawali dengan adanya rohis sekolah yang mengadakan kegiatan dan melibatkan beberapa rohis sekolah yang ada di Maros. Ketua umum Foros Maros, Muh Alwi Alamsyah menuturkan bahwa "pada tahun 2015, terdapat kegiatan rohis sekolah yang melibatkan 4 sekolah, ada juga sekolah dari luar, ada sekitar 5 dan 6, tapi yang jelas itu 4 sekolah, nah perwakilan sekolah ini mengadakan kegiatan Ramadhan, nah disitumi latar belakangnya, karena lain rasanya kalau hanya sekadar kegiatan saja, tidak ada forum bersama, makanya kita buatkan forum, sehingga keempat sekolah ini ceritanya bisa sama ratalah kualitas rohisnya, bisa saling komunikasi atau sharing. Nah hal tersebut membutuhkan Lembaga, makanya dibentuklah Foros."

Berdasarkan latar belakang tersebut, akhirnya Forum Rohis Maros yang pada bulan maret kemarin telah berganti nama secara internal menjadi Forum Komunikasi Kerohanian Islam (FKKI), akhirnya secara resmi membentuk sebuah Lembaga Dakwah pada tanggal 3 Oktober 2015 di Rumah Makan Idaman Kabupaten Maros yang dihadiri oleh perwakilan beberapa sekolah serta alumni rohis sekolah.

Setelah kurang lebih tiga tahun terbentuk sebagai sebuah Lembaga Dakwah, Foros Maros telah berhasil merangkul enam sekolah di Kabupaten Maros, yakni SMAN 1 Maros, SMAN 3 Maros, SMKN 1 Maros, SMA Negeri Angkasa, SMAN 8 Maros, dan SMAN 9 Maros. Selain itu masih ada beberapa sekolah yang masih dalam proses komunikasi untuk dapat bergabung dalam naungan Foros Maros secara resmi, salah satunya adalah SMAN 10 Maros. Jadi, ada beberapa rohis yang dibentuk oleh Foros dibeberapa sekolah, yang sebelumnya tidak memiliki rohis akhirnya dapat terbentuk, seperti SMAN 9 Maros. Selain itu, kehadiran Foros Maros juga dianggap mampu membangkitkan kembali semangat belajar agama serta dakwah pelajar di Kabupaten Maros.

Yazid Fauzan selaku ketua Rohis SMAN 8 Maros mengungkapkan, "Foros Maros membangkitkan kembali semangat kondisi rohis yang terpuruk sehingga dapat bangkit kembali, dulu kayak pasif jarang ada kegiatan, sejak terbentuknya Foros dan kedatangannya kesini, keaktifan anggota semakin meningkat, munculmi kajian, dan bahkan pernah diadakan tablig akbar, dibantu dari segi pemateri dan materi, manfaatnya juga kita lebih dikenal dari sekolah lain, kita juga seperti menambah keluarga." 
Selain itu, Sekretaris Foros menambahkan, "Setiap ada kegiatan beda rasanya kalau Foros yang adakan, ghirah dakwahnya terasa sekali, seperti pas bagi bagi hijab, pokoknya enak sekali rasanya memberi, Enak sekali rasanya kalau ketemu sama orang-orang yang seiman."

Berdasarkan hal tersebut, keberadaan organisasi atau Lembaga Dakwah Islam tentu menjadi sangat penting dalam melestarikan dan menebarkan nilai-nilai Islam kepada masyarakat melalui implementasi berbagai program, kebijakan maupun pemikiran. Dengan memperhatikan berbagai aspek, mulai dari bagaimana cara berdakwah yang baik, serta kegiatan-kegiatan seperti apa yang dapat menunjang tercapainya visi misi Foros Maros sebagai Lembaga Dakwah yang berada dalam pusaran pelajar di Kabupaten Maros.

Sebagaimana yang terdapat dalam Pasal 6 dan 7 Anggaran Dasar (AD) Forum Rohis Maros, dipaparkan bahwa visi dari Foros Maros ialah "Menjadi sarana komunikasi dan koordinasi dakwah Rohis yang terpadu, tangguh, dan professional menuju pelajar yang berkarakter dan berprestasi," Dari hasil wawancara, secara umum para informan mengungkapkan perbedaan kepribadian yang cukup besar antara siswa-siswi yang mengikuti kegiatan rohis dan yang tidak mengikuti kegiatan rohis, baik dari aspek akademis atau prestasi maupun dalam ruang lingkup organisasi.

Hal ini juga didukung oleh ketua rohis SMA Angkasa, Ibrahim yang mengungkapkan, "Kalau saya di SMA angkasa itu yang rangking satu di kelas pasti anak rohis, yang dikenal dan dipercaya itu anak rohis, yang mendominasi ketua ekskul itu anak rohis, yang biasa ikut lomba juga anak rohis, anak rohis memang dipercaya karena kalau anak rohis yang pegang pasti para guru tidak ragu untuk menerima, kalau bukan anak rohis masih berpikirki, karena rohis kan merupakan organisasi agama, insyaa Allah terpercaya.”

Uraian hasil wawancara diatas secara umum menunjukkan keberhasilan rohis sekolah dalam menjalankan tugas dan fungsinya sebagaimana yang terdapat dalam peran dan tujuan rohis antara lain sebagai berikut:

a. Meningkatkan pemahaman terhadap agama sehingga mampu mengembangkan dirinya sesuai norma agama serta mampu mengamalkannya.

b. Meningkatkan kemampuan peserta didik sebagai anggota masyarakat.

c. Menyalurkan dan mengembangkan potensi dan bakat peserta didik.

d. Melatih sikap disiplin, kejujuran, kepercayaan, dan tanggung jawab dalam menjalankan tugas.

e. Menumbuh-kembangkan akhlak Islami yang mengintegrasikan hubungan dengan Allah, Rasul, manusia, dan alam sekitar.

f. Mengembangkan sensitivitas peserta didik dalam melihat persoalan-persoalan sosialkeagamaan sehingga menjadi insan yang proaktif terhadap permasalahan sosial dan dakwah Islamiah.

g. Memberikan bimbingan dan arahan serta pelatihan kepada peserta didik.

h. Memberi peluang peserta didik agar memiliki kemampuan untuk komunikasi yang baik.

i. Melatih kemampuan peserta didik untuk bekerja dengan sebaik-baiknya secara mandiri maupun kelompok.

j. Menumbuh-kembangkan kemampuan peserta didik untuk memecahkan masalah sehari-hari.

Setelah melakukan pengumpulan data salah satunya dengan wawancara, ternyata sebagian besar pengurus Foros Maros tidak mengetahui secara jelas visi serta misi Foros Maros yang tercantum dalam Anggaran Dasar (AD). Sebagaimana ungkapan Zul Fahmi Rasyid, "Nda kutau apa visi misinya kak, astagfirullah. Yang kutau itu intinya Foros itu sebagai forum komunikasi untuk rohis-rohis sekolah yang ada di Kabupaten Maros, nda kutau persis visi misinya." 
Ketidaktahuan mengenai Visi Misi ini tentu membuat proses berjalannya sebuah Lembaga Dakwah menuai banyak kendala, membuat setiap anggota kehilangan semangat, sebab mereka tidak memahami tujuan dari Lembaga Dakwah tersebut. Memahami tujuan sebuah Lembaga tentu akan sangat memudahkan seluruh anggota Lembaga Dakwah tersebut untuk membuat serta memetakan strategi yang dapat dilakukan untuk mencapai tujuan. Secara logika, bagaimana mungkin seseorang dapat mewujudkan cita-cita atau mencapai tujuan jika apa yang dituju tersebut tidak dipahami?

Arham Maulana selaku ketua rohis SMA Negeri 1 Maros sekaligus menjabat sebagai ketua bidang Pendidikan dan dakwah Foros Maros mengungkapkan bahwa sebenarnya ghirah para pelajar untuk belajar agama sangatlah tinggi, "Sangat luar biasa semangatnya kak ikut kajian, dapat dilihat kalau ada kegiatan tablig akbar sangat antusiasiki dan berbondongbondongki untuk hadir, seperti tablig akbar yang diadakan sama sahabat hijrah Maros yang baru baru ini diadakan di al markas, itupun adek adek sering mengajak untuk pergi tablig akbar sama sama."

Hal ini juga didukung dengan pernyataan dari dewan alumni Foros Maros yang mengatakan, "Kalau kita mengamati ada pergeseran yang terjadi, pergeseran kebudayaan, pergeseran kebiasaan, yang tadinya mungkin kalau Maros pelajarnya kurang yang mau ikut terlibat dalam kegiatan dakwah, semakin kesini itu kegiatan dakwah semakin di kemas dengan cara-cara millenial, sehingga semakin banyak yang tertarik, jadi semakin kesini itu semakin berkembang keinginannya pelajar untuk berpartisipasi dalam kegiatan-kegiatan islam, walaupun tidak semua."

Berdasarkan hal tersebut, sebenarnya keberadaan Foros Maros sebagai Lembaga Dakwah yang fokus sebagai forum komunikasi bagi setiap rohis sekolah, secara tidak langsung turun andil dalam meningkatkan semangat para pelajar dalam mempelajari atau memahami agamanya serta betapa pentingnya nilai-nilai islam diimplemenasikan dalam kehidupan seharihari, dengan berbagai program yang berupaya dihadirkan meskipun belum berlangsung secara maksimal.

Kehadiran Foros Maros ini sebenarnya juga memiliki misi lain, yakni mencegah lahirnya bibit-bibit radikalisme dikalangan pelajar. Tak dapat dipungkiri, bahwa beberapa tahun terakhir ini isu radikalisme dikalangan masyarakat semakin menyeruak, sangst disayangkan para pelajar turut menjadi sasaran untuk paham-paham tersebut. Disadur dari portal Tribunnews.com dengan judul berita Radikalisme di Kalangan Pelajar dan Mahasiswa Jadi Bahan Evaluasi Penerapan Kurikulum Pendidikan, Direktur Kemahasiswaan Ditjen Pembelajaran dan Kemahasiswaan Kemenristekdikti, mengatakan bahwa hasil survei dari Alvara Research Center menyatakan sekitar 23,4 persen mahasiswa dan pelajar terjangkit paham radikal.

Selain itu data pendukung hal ini juga dapat dilihat dari survei yang dilakukan oleh PPIM UIN Syarif Hidayatullah pada akhir 2017 menunjukkan adanya potensi radikalisme di kalangan generasi Z, yaitu generasi yang lahir sejak pertengan 1990an sampai pertengahan 2000 an. Temuannya adalah sebesar 37,71 persen memandang bahwa jihad atau khital, alias perang, terutama perang melawan non-muslim. Selanjutnya 23,35 persen setuju bahwa bom bunuh diri itu jihad islam. Lalu 34,03 persen setuju kalau muslim yang murtad harus dibunuh. Temuan lain, 33,34 persen berpendapat perbuatan intoleran terhadap kelompok minoritas tidak bermasalah. Para generasi $\mathrm{Z}$ ini banyak memperoleh informasi mengenai materi islam dari internet dan medsos.

\section{b. Tujuan dan Ruang Lingkup Forum Rohis Maros (Foros Maros)}

Foros Maros merupakan forum silaturahim dan Gerakan Pelajar Muslim, sehingga membutuhkan sinergitas antar lembaga. Tujuan dan ruang lingkup Forum Rohis Maros (Foros Maros) dierjemahkan dalam sebuah Visi Misi Forum Rohis Maros (Foros Maros), terdapat di 
Pasal 6 dan 7 Anggaran Dasar (AD) Forum Rohis Maros, yakni Visi "Menjadi sarana komunikasi dan koordinasi dakwah Rohis yang terpadu, tangguh, dan professional menuju pelajar yang berkarakter dan berprestasi". Serta Misi yang terdiri atas 7 poin antara lain sebagai berikut.

a. Membangun silaturahim antar Rohis.

b. Membangun karakter pribadi pelajar Muslim.

c. Menghidupkan dakwah Islam di lingkungan pelajar dan masyarakat.

d. Menjalin hubungan kemitraan strategis dan taktis dalam kegiatan sosial keagamaan.

e. Menjadi sarana dalam pendampingan dan pembinaan Rohis.

f. Memberikan nuansa Islam dalam berbagai aktivitas atau kegiatan yang dikelola siswa maupun sekolah.

g. Menjadi sarana peningkatan profesionalisme pengelolaan Rohis dan perencanaan dakwah.

Forum Rohis Maros (Foros Maros) ini diharapkan dapat menunjang fungsi Pendidikan Nasional yang tercantum dalam dalam Undang-Undang Republik Indonesia No. 20 Tahun 2003 tentang Sistem Pendidikan Nasional pada Bab II Pasal 3 yang menyatakan bahwa:

Pendidikan Nasional berfungsi mengembangkan kemampuan dan membentuk watak serta peradaban bangsa yang bermartabat dalam rangka mencerdaskan kehidupan bangsa, bertujuan untuk berkembangnya potensi peserta didik agar menjadi manusia yang beriman dan bertakwa kepada Tuhan Yang Maha Esa, berakhlak mulia, sehat, berilmu, cakap, kreatif, mandiri, dan menjadi warga negara yang demokratis serta tanggung jawab.

Berdasarkan penjelasan diatas, Forum Rohis Maros (Foros Maros) sebagai salah satu Lembaga Dakwah bertujuan untuk menghimpun setiap rohis sekolah yang ada di Kabupaten Maros dengan melakukan berbagai bentuk kegiatan demi membangun karakter pribadi pelajar muslim agar dapat menunjang segala aspek kehidupan dalam menjalan keseharian di sekolah maupun masyarakat secara umum.

\section{Pelaksanaan Kegiatan Forum Rohis Maros terhadap Pengembangan Dakwah di Kabupaten Maros}

Dalam upaya memaksimalkan proses pelaksanaan kegiatannya, Forum Rohis Maros terdiri atas 6 seksi bidang dan masing-masing seksi bidang memiliki tugas dan wewenang yang berbeda.

Dalam pelaksanaan kegiatan tersebut setiap anggota Foros yang tersebar di berbagai sekolah berhak untuk memilih makanan ataupun barang yang ingin dijual sebagai bentuk penggalangan dana, program ini telah berjalan meskipun tidak maksimal, sebab tidak semua sekolah melakukan penggalangan dana bahkan hanya sedikit yang mencapai target. Selain itu, untuk menambah profit, Foros Maros melakukan penjualan pulsa serta menjual aksesoris, seperti masker, jilbab, kaos kaki, serta makanan yang kemudian di perjualbelikan di Sekolah Putri Darul Istiqamah Mart. Foros Maros juga pernah melaksanakan bazar café untuk menambah dana kegiatan yang akan dijalankan. Selain dari pemasukan tersebut, setiap anggota rohis juga dikenakan iuran perbulan sebesar lima ribu rupiah dan dikumpul ke bendahara Foros Maros. Dana yang terkumpul tentu akan dipergunakan dalam setiap kegiatan yang bertujuan untuk mengembangkan dakwah di Kabupaten Maros.

Untuk lebih jelas mengenai perlaksanaan program kerja Forum Rohis Maros maka peneliti membuat tabel sebagai berikut: 
Tabel 1. Pelaksanaan Program Kerja Sementara Forum Rohis Maros

\begin{tabular}{|c|c|c|c|c|}
\hline \multirow{2}{*}{ No. } & \multirow{2}{*}{ Nama Kegiatan } & \multicolumn{2}{|c|}{ Pelaksanaan } & \multirow{2}{*}{ Keterangan } \\
\hline & & Terlaksana & $\begin{array}{c}\text { Belum } \\
\text { Terlaksana }\end{array}$ & \\
\hline 1 & $\begin{array}{l}\text { Melaksanakan } \\
\text { pengkaderan pengurus / } \\
\text { Latihan Dasar } \\
\text { Kepemimpinan }\end{array}$ & $\checkmark$ & & $\begin{array}{l}\text { Telah dilaksanakan dengan } \\
\text { maksimal pada tanggal 19-21 } \\
\text { April 2019 (Dokumentasi } \\
\text { terlampir) }\end{array}$ \\
\hline 2 & $\begin{array}{l}\text { Melaksanakan kegiatan } \\
\text { Pelantikan Pengurus }\end{array}$ & $\checkmark$ & & $\begin{array}{l}\text { Telah dilaksanakan dengan } \\
\text { maksimal pada tanggal } 13 \\
\text { Oktober } 2019 \text { (Dokumentasi } \\
\text { terlampir) }\end{array}$ \\
\hline 3 & $\begin{array}{l}\text { Mengontrol liqo } \\
\text { tarbiyah setiap rohis di } \\
\text { kabupaten Maros }\end{array}$ & $\checkmark$ & & $\begin{array}{l}\text { Belum maksimal (karena } \\
\text { komunikasi yang dilakukan } \\
\text { oleh penanggung jawab } \\
\text { kepada setiap rohis sekolah } \\
\text { masih tidak terlalu intens) }\end{array}$ \\
\hline 4 & $\begin{array}{l}\text { Mengadakan pengajian } \\
\text { rutin disetiap rohis }\end{array}$ & $\checkmark$ & & $\begin{array}{l}\text { Cukup maksimal } \\
\text { (karena masih ada beberapa } \\
\text { sekolah yang tidak } \\
\text { mengadakan pengajian rutin } \\
\text { setiap pekan) }\end{array}$ \\
\hline 5 & $\begin{array}{l}\text { Melaksanakan kegiatan } \\
\text { tabligh akbar }\end{array}$ & & $\checkmark$ & $\begin{array}{l}\text { Belum terlaksana karena } \\
\text { permasalahan anggaran dana }\end{array}$ \\
\hline 6 & $\begin{array}{l}\text { Melaksanakan kegiatan } \\
\text { Rohis Peduli } \\
\text { Masyarakat (RPM) }\end{array}$ & $\checkmark$ & & $\begin{array}{l}\text { Telah terlaksana dengan } \\
\text { maksimal sebanyak tiga kali } \\
\text { (Dokumentasi terlampir) }\end{array}$ \\
\hline 7 & $\begin{array}{l}\text { Melaksanakan kegiatan } \\
\text { Kemah Rohis III }\end{array}$ & & $\checkmark$ & $\begin{array}{l}\text { Rencana dilaksanakan pada } \\
\text { bulan Desember }\end{array}$ \\
\hline 8 & $\begin{array}{l}\text { Melaksanakan kegiatan } \\
\text { World Hijab Day }\end{array}$ & $\checkmark$ & & $\begin{array}{l}\text { Telah terlaksana dengan } \\
\text { maksimal } \\
\text { terlampir) }\end{array}$ \\
\hline 9 & $\begin{array}{l}\text { Mendokumentasikan } \\
\text { setiap kegiatan FOROS }\end{array}$ & $\checkmark$ & & $\begin{array}{l}\text { Telah terlaksana. } \\
\text { (Dokumentasi terlampir) }\end{array}$ \\
\hline 10 & $\begin{array}{l}\text { Mengaktifkan semua } \\
\text { akun social FOROS }\end{array}$ & $\checkmark$ & & (Dokumentasi terlampir) \\
\hline 11 & $\begin{array}{l}\text { Membuat pamphlet dan } \\
\text { broadcast }\end{array}$ & $\checkmark$ & & $\begin{array}{l}\text { Belum maksimal } \\
\text { (karena masih ada beberapa } \\
\text { mis komunikasi dan } \\
\text { koordinasi yang terjadi antar } \\
\text { pengurus) }\end{array}$ \\
\hline 12 & $\begin{array}{l}\text { Melaksankan seminar } \\
\text { kemuslimahan }\end{array}$ & & $\checkmark$ & $\begin{array}{l}\text { Rencana dilaksanakan pada } \\
\text { bulan Desember }\end{array}$ \\
\hline 13 & $\begin{array}{l}\text { Melaksanakan kegiatan } \\
\text { hari bersama sahabat } \\
\text { (Harber) }\end{array}$ & & $\checkmark$ & Belum terlaksana \\
\hline
\end{tabular}




\begin{tabular}{|c|c|c|c|}
\hline 14 & $\begin{array}{l}\text { Mengadakan dan } \\
\text { mengontrol } \\
\text { penggalangan dana di } \\
\text { setiap sekolah }\end{array}$ & $\checkmark$ & $\begin{array}{l}\text { Belum maksimal (karena } \\
\text { komunikasi serta koordinasi } \\
\text { tidak dilakukan secara intens } \\
\text { dengan penagnggung jawab } \\
\text { tiap sekolah) }\end{array}$ \\
\hline 15 & $\begin{array}{l}\text { Menjual pulsa, } \\
\text { perlengkapan } \\
\text { muslimah, makanan } \\
\text { dan lain-lain }\end{array}$ & $\checkmark$ & $\begin{array}{l}\text { Telah terlaksana dengan } \\
\text { cukup maksimal (karena hasil } \\
\text { yang diperoleh lumayan } \\
\text { besar dan dapat dipergunakan } \\
\text { untuk membantu pelaksanaan } \\
\text { kegiatan Foros Maros. }\end{array}$ \\
\hline 16 & $\begin{array}{l}\text { Mengadakan } \\
\text { Silaturahim Antar } \\
\text { Rohis }\end{array}$ & $\checkmark$ & $\begin{array}{l}\text { Telah dilaksanakan dengan } \\
\text { maksimal pada tanggal } 7 \text { Juli } \\
2019 \text { karena menghadirkan } \\
\text { beberapa perwakilan rohis } \\
\text { sekolah yang akhirnya juga } \\
\text { berinisiatif untuk bergabung } \\
\text { dengan Foros Maros) }\end{array}$ \\
\hline 17 & $\begin{array}{l}\text { Mengadakan } \\
\text { almamater/baju kerja }\end{array}$ & & $\begin{array}{l}\text { Belum terlaksana karena } \\
\text { permasalahan dana. }\end{array}$ \\
\hline 18 & $\begin{array}{l}\text { Membuat database } \\
\text { pengurus }\end{array}$ & $\checkmark$ & $\begin{array}{l}\text { Telah terlaksana dengan } \\
\text { maksimal }\end{array}$ \\
\hline 19 & $\begin{array}{l}\text { Mengumpulkan iuran } \\
\text { perbulan }\end{array}$ & $\checkmark$ & $\begin{array}{l}\text { Telah terlaksana, namun } \\
\text { belum berjalan secara } \\
\text { maksimal karena masih } \\
\text { kesulitan } \\
\text { mengumpulkan iuaran yang } \\
\text { disebabkan sekolah yang } \\
\text { berbeda-beda }\end{array}$ \\
\hline
\end{tabular}

Berdasarkan hasil penelitian yang diperoleh, pelaksanaan kegiatan telah berjalan maksimal, hal ini dapat dilihat dari program kerja yang telah terlaksana dari 6 seksi bidang yang ada dalam kepengurusan Foros Maros periode ini yang tentu berkaitan dengan upaya Foros Maros sebagai Lembaga Dakwah dalam mengembangkan dakwah di Kabupaten Maros. Walaupun masih ada beberapa kegiatan yang belum berjalan maksimal dan masih dalam proses perencanaan, para pengurus Foros Maros tetap optimis mampu mencapai visi misi nya yang terdapat dalam $\mathrm{AD} / \mathrm{ART}$ dengan mulai kembali menyusun jadwal atau perencanaan program kerja yang berkelanjutan.

3. Faktor Pendukung dan Faktor Penghambat Pelaksanaan Program Kerja Forum Rohis Maros terhadap Pengembangan Dakwah di Kabupaen Maros

Sebagai sebuah Lembaga Dakwah yang baru berdiri selama kurang lebih tiga tahun, orang-orang yang tergabung dalam Forum Rohis Maros terus berusaha membangun semangat demi terwujudnya visi misi yang tercantum dalam Anggaran Dasar Foros Maros, terdapat berbagai faktor pendukung dan penghambat yang mempengaruhi proses berjalannya segala pelaksanaan program kerja Forum Rohis Maros terhadap pengembangan dakwah di Kabupaten Maros. Faktor pendukung dan faktor penghambat tersebut dapat ditinjau melalui tahapan manajemen dakwah yang dilakukan, antara lain sebagai berikut. 


\section{a. Faktor Pendukung}

\section{1) Perencanaan Dakwah (Takhthith)}

Rencana adalah suatu arah tindakan yang sudah ditentukan terlebih dahulu. Dari perencanaan ini akan mengungkapkan tujuan-tujuan keorganisasian dan kegiatan-kegiatan yang diperlukan guna mencapai tujuan. Dalam aktivitas dakwah, perencanaan dakwah dilakukan dengan menentukan langkah dan program pada setiap sasaran dakwah (mad'u), menentukan sarana prasarana atau media dakwah, serta personel da'i yang akan diterjunkan.

Dalam proses pelaksanaan program kerja Forum Rohis Maros, salah satu faktor pendukunya ialah perencanaan dakwah yang dilakukan dengan maksimal, misalnya kegiatan World Hijab Day. World Hijab Day merupakan kegiatan yang rutin dilaksanakan setiap tahun, setiap orang yang terlibat didalamnya menjalankan tanggung jawabnya dengan semaksimal mungkin. Dengan menjadikan kegiatan tahun lalu sebagai referensi, konsep yang dibuat untuk kegiatan ini direncanakan dan dijalankan dengan jauh lebih baik.

Dalam proses wawancara, Erni Evitasari menuturkan, "World Hijab Day (WHD) tahun ini itu lebih meningkat kak dari tahun sebelumnya. WHD tahun setiap rohis kek bawa satu massa yang banyak jadi lebih ramai, beda dengan tahun lalu yang dominan anak smansa menurutku. Terus lebih akrab dengan rohis sekolah lain. Sebelum jalan dan bagikan jilbab di lampu merah dan sekitaran Pantai Tak Berombak (PTB) ada kajiannya, selain itu jumlah hijab yang terkumpul lebih banyak kak, ada sekitar 200an lebih, dan itumi yang dibagikan ke masyarakat yang lewat, beserta dengan stiker sama kata-kata mutiara."

2) Pengorganisasian Dakwah (Thanzim)

Pengorganisasian adalah proses pengelompokan sumber daya manusia (sdm), sarana dan prasarana, sumber daya keuangan, dan job description sedemikian rupa agar tercipta suatu organisasi yang dapat bergerak dalam satu kesatuan untuk mencapai tujuan yang telah ditetapkan. Definisi tersebut menunjukkan bahwa pengorganisasian merupakan langkah pertama ke arah pelaksanaan rencana yang telah disusun sebelumnya.

Dalam proses pelaksanaan kegiatannya, para pengurus Foros Maros telah berbagi job description, baik itu dalam skala kegiatan yang besar dan membutuhkan kepanitiaan serta melibatkan rohis sekolah, maupun hanya dalam bentuk timwork. Selain job description, hal penting dalam pengorganisasian dakwah ialah ketersediaan dana dalam menjalankan kegiatan. Salah satu kegiatan yang berjalan lancar karena pengorganisasian dakwah yang baik ialah kegiatan World Hijab Day serta Seminar Kemuslimahan, kegiatan ini berlangsung cukup baik karena dalam pelaksanaannya ketua umum memberikan tugas dan tanggung jawab kepada setiap anggota.

3) Penggerakan Dakwah

Penggerakan dakwah adalah langkah lanjutan dari perencanaan dan pengorganisasian dakwah, setelah seluruh tindakan dipilah-pilah menurut bidang tugas masing-masing. Inti kegiatan penggerakan dakwah adalah bagaimana seorang pemimpin menyadarkan seluruh elemen organisasi untuk dapat bergerak Bersama dan bekerjasama secara sinergis untuk menjalankan program organisasi.

Dalam menjalankan program kerjanya, salah satu faktor pendukung dari terlaksananya program kerja Foros Maros ialah arahan dari pemimpin serta semangat yang diberikan kepada setiap anggota. Hal ini dapat dilihat kegiatan Rohis Peduli Masyarakat yang telah berlangsung sebanyak tiga kali, dan salah satu kegiatan Rohis Peduli Masyarakat juga sempat dijalankan di salah satu desa yang memiliki jarak tempuh yang cukup jauh dari kota.

4) Pengendalian dan evaluasi dakwah

Pengendalian dakwah akan membantu seorang manajer dakwah untuk memonitor efektifitas kegiatan perencanaan, pengorganisasian, serta kepemimpinan mereka. Pengendalian dakwah dilakukan dengan cara menetapkan standar yang menjadi tolak ukur kinerja organisasi 
yang berjalan secara efektif, efisien, dan produktif, dilanjutkan dengan proses pengukuran kinerja yang terjadi secara real di lapangan dengan tolak ukur yang sudah ditetapkan, dari sana akan terlihat lini dakwah yang berjalan dengan baik atau tidak.

Dalam proses pengendalian dan mengevaluasi, sebuah Lembaga Dakwah harus memperhatikan beberapa hal, yatu:

(1) Efek kognitif, yaitu timbul jika ada perubahan pada apa yang diketahui, dipahami, dan dipersepsi oleh khalayak.

(2) Efek afektif, yaitu efek yang timbul jika ada perubahan pada apa yang dirasakan, disenangi, atau dibenci khalayak.

(3) Efek behavioral, yaitu merujuk pada perilaku nyata yang dapat diamati, yang meliputi pola-pola tindakan, kegiatan, atau kebiasaan tindakan berperilaku

Dalam melaksanakan setiap program kerjanya, Foros seringkali melaksanakan evaluasi setelah kegiatan berlangsung, selain itu terdapat peran dari para dewan alumni untuk memonitoring secara langsung kegiatan yang telah dilakukan oleh Foros Maros.

\section{b. Faktor Penghambat}

1) Permasalahan Anggaran

Kurangnya ketersediaan anggaran dana dalam sebuah kegiatan menjadi salah satu faktor penghambat Foros Maros dalam menjalankan setiap kegiatannya secara maksimal. Ketua bidang Pendidikan dan dakwah mengungkapkan bahwa salah satu strategi yang dapat dilakukan agar pelaksanaan kegiatan Foros Maros dapat berjalan dengan baik ialah dengan memaksimalkan kembali seksi bidang dana dan usaha, sebab sebagian dana yang diperolah oleh Foros hanya berasal dari penggalangan dana yang profitnya hanya sedikit, seandainya Foros Maros menerima sumbangan dana dari pihak pemerintahan kabupaten Maros mungkin pelaksanaan kegiatan Foros Maros akan berjalan lebih maksimal.

2) Kurangnya komunikasi dan koordinasi antar anggota

Faktor penghambat yang juga sering kali terjadi dalam pengorganisasian dakwah Forum Rohis Maros ialah masalah koordinasi dan komunikasi antar anggota. Ketua Umum Foros Maros, Alwi Alamsyah mengungkapkan, "Komunikasi dan koordinasinya memang masih tidak terlalu bagus, masih ada yang merasa terasingkan bukan terasingkan tapi karena pemalu. Biasa juga ada yang tiba-tiba hilang susah dihubungi."

Dari hasil wawancara, peneliti juga menemukan bahwa masih ada beberapa anggota yang tidak terlalu paham mengenai jalur koordinasi, misalnya seksi bidang syiar yang telah membuat pesan-pesan dakwah dengan mendesain sebuah pamphlet yang sayangnya tidak terpublikasikan karena kurangnya komunikasi serta koordinasi dengan seksi bidang humas yang bertugas untuk mempublikasikan pesan-pesan dakwah tersebut di media sosial. Hal ini juga membuat beberapa pengurus tidak menjalankan tanggung jawabnya secara maksimal. Selain itu, beberapa bulan terakhir ini beberapa pengurus merasa masih kurangnya arahan dalam hal komunikasi maupun koordinasi dari pemimpin kepada anggotanya.

3) Kurangnya dukungan dari pihak sekolah maupun pemerintah

Kurangnya dukungan dari pihak sekolah maupun pemerintah juga menjadi salah satu penghambat yang cukup besar dalam setiap pelaksanaan kegiatan Foros Maros. Pihak sekolah harusnya lebih banyak mengajak para siswa-siswi untuk aktif dalam kegiatan kegamaan. Selain itu, peran pihak pemerintah dalam hal ini kementerian agama masih kurang dalam mengawasi jalannya setiap kegiatan Foros Maros.

Dalam proses wawancara, Yudi Renata mengungkapkan, "Dulu kita berada dibawah naungannya kementerian tapi pada akhirnya akhir-akhir ini agak sulit untuk mempertemukan keinginannya kementrian agama dan keinginannya Foros, dan yang saya rasakan sendiri itu di kementerian agama itu fokusnya adalah menyelesaikan program, follow up nya yang harusnya di serahkan kepada Foros, tapi tidak. Semestinya kegiatan kegiatan kementerian harus 
melibatkan Foros sebagai perpanjangan tangan, tapi yang ada malah dia atau kementerian yang langsung turun ke bawah. Beda di awal awal dulu, kalau di awal awal dulu kita memang sering sharing dengan kementerian, nah sekarang sudah tidak."

Meskipun demikian pengurus Foros Maros mengungkapkan bahwa mereka kembali akan berkoordinasi dengan pihak kementerian serta orang-orang yang akan terlibat dalam pelaksanaan kegiatan Foros agar kegiatan-kegiatan yang dijalankan Foros Maros akan berlangsung dengan lancar dan lebih baik dari kegiatan-kegiatan sebelumnya.

\section{DAFTAR PUSTAKA}

Aripuddin, Acep, Pengembangan metode dakwah, Jakarta: Rajawali Pers, 2011

Aziz, Moh. Ali, Ilmu Dakwah, Cet.II; Jakarta: Kencana, 2009

Badan Pengembangan dan Pembinaan Bahasa Kementerian Pendidikan dan Kebudayaan RI, Kamus Besar Bahasa Indonesia, Ed. V; Jakarta, PT Gramedia Pustaka Utama, 2016

Departemen Agama RI, Al-Qur'an dan Terjemahnya, Bandung: Syaamil Qur'an, 2012

Ejang AS, Dasar-Dasar Ilmu Dakwah, Cet. I; Bandung: Widya Padjadjaran, 2009

Ernawati, Sri, Peran Kerohanian Islam (Rohis) terhadap Pembentukan Akhlak dan Kesadaran Beragama Peserta Didik di SMK Negeri 1 Klaten, Skripsi; Yogyakarta: Universitas Islam Negeri Sunan Kalijaga Yogyakarta: 2017

Firmansyah, Julnis, 2018, Tawuran Pelajar 2019 Lebih Tinggi Dibanding Tahun Lalu. https://metro.tempo.co/read/1125876/kpai-tawuran-pelajar-2018-lebih-tinggidibanding-tahun-lalu, diakses pada tanggal 30 Maret 2019

Hamriani, Organisasi dalam manajemen dakwah, Jurnal; Vol. 14; Makassar: Universitas Islam Negeri Alauddin Makassar: 2013

Ismail, Ilyas dan Hotman, Prio, Filsafat Dakwah Rekayasa Membangun Agama dan Peradaban, Cet. I; Jakarta: Kencana, 2011

Kanal Informasi, 2016, Definisi Forum, Definisiforumkanalinfo.web.id, diakses pada tanggal 25 Maret 2019

Kusnawan, Asep dkk, Dimensi ilmu dakwah, Bandung: Widya Padjadjaran, 2009

M. Anwar, Pengaruh Kegiatan Kerohanian Islam (Rohis) terhadap Pengembangan Afektif SIswa, Jurnal; Bogor: Universitas Djuanda Bogor: 2015

M. Arifin, Psikologi Dakwah Suatu Pengantar, Jakarta: Bumi Aksara, 1997

M. Munir, Metode Dakwah, Cet. III; Jakarta: Kencana, 2009

M. Munir, dan Wahyu Ilaihi, Manajemen Dakwah, Cet.II; Jakarta: Kencana Prenada Media Group, 2009

Nurdin, Nasrullah, Pedoman Pembinaan Rohis di Sekolah dan Madrasah, Jakarta: Erlangga, 2018

Republik Indonesia, Undang-Undang No. 20 Tahun 2003 Tentang Sistem Pendidikan Nasional.

Sanjaya, Wina, Penelitian Pendidikan: Jenis, Metode, dan Prosedur, Cet. I; Jakarta: PT Kencana Prenada Media Grup, 2013

Shihab, Quraisy Tafsir Al-misbah, vol: 7, Jakarta: Lentera Hati, 2002, h:385-386.

Soekanto, Soerjono, Sosiologi Suatu Pengantar, Jakarta: Rajawali Pers, 2009

Wahyu, Ilaihi, Komunikasi Dakwah, Bandung: PT. Remaja Rosda Karya, 2010

Yusuf, Muri, Metode Penelitian Kuantitatif, Kualitatif dan Penelitian Gabungan, Cet.II; Jakarta: Kencana, 2014 